\title{
KDM5B wt Allele
}

National Cancer Institute

\section{Source}

National Cancer Institute. KDM5B wt Allele. NCI Thesaurus. Code C51295.

Human KDM5B wild-type allele is located in the vicinity of $1 \mathrm{q} 32.1$ and is approximately 82 $\mathrm{kb}$ in length. This allele, which encodes lysine-specific demethylase 5B protein plays a role in RB tumor suppressor regulation. 